\title{
Aprofundamento e abrangência
}

Em certos momentos, o editor de uma revista científica pode se sentir como um técnico de time de futebol tendo mais de um craque para escalar na mesma posição. A Revista Brasileira de Otorrinolaringologia vem paulatinamente acumulando este tipo de dilema. Como aproveitar todos no time. Nossa política editorial tem se pautado em um contínuo aperfeiçoamento do processo de avaliação, com a conseqüente elevação do rigor dos critérios de seleção. Imaginávamos que com esta atitude veríamos o fluxo de trabalhos enviados à revista diminuir. O fluxo aumentou, e mais, melhorou muito o nível dos trabalhos recebidos. De certa forma, o problema tem se transformado em solução, pois pudemos com a maior quantidade de artigos relativos aos diversos interesses dentro da Otorrinolaringologia, agrupálos em seções informais que favoreceram a leitura de acordo com o interesse do leitor.

Temos feito este agrupamento há três números e vínhamos meditando sobre a possibilidade de transformar as seções informais em seções formalizadas já no índice. Mas aí surgiu a dúvida: quais seriam as seções? Naturalmente poderiam ser Otologia, Rinologia e Laringologia. Temos inclusive sociedades de supra-especialidades com estes nomes. Mas e a Cabeça e Pescoço, a Pediatria, a Cirurgia Estética e Reconstrutora da face, a Medicina do Trabalho, etc, etc, etc...?

Este dilema nos fez meditar sobre os rumos que a especialidade vem tomando do ponto de vista acadêmico. As nossas reflexões nos levaram aos primórdios da profissão.

Partindo do pressuposto que o momento em que a Medicina teve início é tema de conjecturas, uma vez que não existem escritos relativos ao assunto. E sendo os desenhos pré-históricos que sobreviveram às intempéries do tempo, representantes de uma fase relativamente tardia da era do homem da pedra, consideramos que é extremamente difícil estabelecer as premissas básicas que determinaram a inclinação do homem em direção ao exercício da profissão médica. Sabemos que mágicos e homens da Medicina constituem a mais velha classe profissional de que se tem conhecimento. Na caverna dos Trois Frères, nas montanhas Pirineus da França está desenhado o dito mais velho "médico" da humanidade jamais documentado. Os desenhos datam de 15.000 A.C.

As evidências de atividades relativas à práticas curativas estão conservadas em crânios pré-históricos onde sinais bastante claros de trepanação estão presentes.
Estas evidências são escassas, mas podem nos informar um pouco sobre as motivações e crenças que incitaram nossos antepassados a atuarem na profissão primitiva.

Diversos autores estudaram o assunto e a síntese de suas investigações pode ser descrita em dois tópicos: 1-a procura da extirpação de algum material mórbido ou influência daninha sobre a vítima e 2- o resgate da alma, ora abstraída do corpo do enfermo.

O caso das trepanações parece ter servido para as duas coisas, uma vez que pelo orifício craniano poderia haver a saída de maus espíritos do corpo do afligido ao mesmo tempo em que favoreceria a cura de lesões traumáticas por drenagem da região.

Provavelmente o primeiro motivo era o mais indicado, sendo a "Medicina" pré-histórica baseada em uma atitude animística em relação à doença. Por esta visão, a doença era causada pela má influência do demônio, de um inimigo, de um deus, ou mesmo de um animal, e deveria ser cuidada de acordo através do deslocamento desta causa malevolente do corpo do paciente. Em escritos através de toda a história da atividade médica há relatos sobre a necessidade do sabor desagradável e da natureza repelente dos medicamentos para que pudesse fazer efeito. Esta é uma indicação, segundo estudiosos, do intuito de deslocar as forças do mal através de artifícios repugnantes. Na cidade de Cheshire, Inglaterra, havia um remédio para aftas ulcerosas da boca que consistia em manter um sapo vivo na boca por alguns minutos e depois deixá-lo sair. Com esta manobra a causa da moléstia seria transferida para o sapo, afastando-se do aflito. Em 430 A.C., Heródoto nos conta que cada babilônio era um médico amador, pois era costume na época deitar os enfermos na rua para que os passantes pudessem ajudá-lo com seus conhecimentos sobre sua doença. Dizia ele "se ele alguma vez sofreu da mesma doença, ou tiver conhecido alguém que a tivesse tido, poderia dar ao doente algum conselho... e a ninguém era permitido passar por um homem doente em silêncio".

A literatura médica começava e muitos outros casos foram exemplarmente descritos, juntamente com a prescrição necessária para sua cura. Surpreendentemente moderna é a descrição de um paciente com sua mandíbula deslocada "Se você examinar um homem com uma mandỉbula deslocada, deverá encontrar sua boca aberta, sem que possa fechá-la. Você deverá colocar seus dois polegares 
sobre o fim de cada um dos ramos da mandíbula dentro da boca e seus dedos sobre o queixo e deverá causar sua queda para trás de maneira que a mandíbula volte ao seu lugar" (2.000 A.C).

Os papiros médicos foram muitos. Um grupo em particular teve grande influência na profissão no antigo Egito. Esta coleção de informações médicas foi chamada de "Os livros Herméticos" e tinha tamanha estima junto aos faraós que não se imputava culpa ao praticante da Medicina que tivesse um paciente morto após o tratamento, se este tivesse seguido os seus ensinamentos. Entretanto, se o médico não perpetrasse métodos aconselhados por eles e seu paciente viesse a falecer, pagaria com a própria vida.

Percebemos já aqui, uma obstinada procura pela atuação sistemática junto ao paciente e a extrema responsabilidade imputada ao praticante da arte de curar.

A sistemática provinha de crenças de origem desconhecida, mas tinha uma lógica interna que determinava o rumo da atuação médica. Um dos caminhos da sistematização se dirigiu à especialização das atividades da arte de curar. Este processo se iniciou no começo do século XIX. Ambas as cadeiras, clínica e cirúrgica, entraram no processo no mesmo momento, mas foi a Cirurgia que teve uma definição mais rápida e marcada. No final do XIX ${ }^{o}$ século já existia a Cirurgia do abdome e a Neurocirurgia. A Ortopedia que já vinha sendo praticada como especialidade desde o meio do século XVIII foi assim denominada após a primeira grande guerra. A Otorrinolaringologia surgiu como especialidade um pouco mais tarde que as outras especialidades cirúrgicas e bem depois que algumas especialidades clínicas como a Pediatria, Cardiologia e Endocrinologia. Entretanto, o assunto chamava a atenção de nossos colegas desde meados de 1600, quando já existia notícia de tratados lidando com a Anatomia da orelha. A partir de então, surgem esforços para que o tratamento das doenças da orelha fosse feito a partir de uma base científica. Um dos grandes acontecimentos nesta cruzada foi a fundação, em 1805, do Dispensário Londrino para a cura das doenças dos olhos e orelhas. Pouco mais tarde, em 1838, é a vez do Hospital Metropolitano para orelha e garganta, inaugurando o nome Oto-Laringologia. A Rinofaringologia foi incorporada à especialidade um pouco mais tarde, provavelmente em torno de 1860, uma vez que já em 1880 era lançado o periódico Revue de Laryngologie-OtologieRhinologie, de Bordeaux.
Percebemos, ao observar o desenrolar dos fatos, que a ORL foi agregando conhecimentos especiais e construindo, tijolo a tijolo, os pilares da especialidade. Passados mais de cem anos de nossa instituição, vislumbramos um modus operandi e mais ainda, um modus pensanti do indivíduo formado nas artes curativas otorrinolaringológicas. Esta atitude representa uma maneira de raciocinar que foi lapidada por mais de um século por homens que tinham uma visão abrangente da ORL sem, contudo, deixarem de se aprofundar nos temas mais complexos da especialidade. Aprofundamento e abrangência: este é um binômio não muito simples de se obter. No geral, quanto mais absortos estamos em determinado assunto, menos horizontes atingimos com o olhar. O mesmo ocorrendo na via inversa. Este talvez seja o dilema da Revista atualmente, especializar, aprofundar ou abarcar com braços largos? Este dilema talvez possa ser dividido com nossas sociedades de supraespecialidades. Não poderiam ser elas os esteios acadêmicos da Sociedade-mãe, enquanto esta se preocuparia em lutar por melhores condições para o exercício ético e competente da Otorrinolaringologia. Mas, se funcionassem separadas da SBORL, não poderiam dar chance ao retorno aos primórdios da especialidade, onde Oto não era Laringo e Rino não era nada?

A competência e a habilitação são atributos fundamentais e desejados por todos os médicos. Uma das maneiras mais salutares de se atingir a competência médica é através do uso crítico das informações produzidas pela pesquisa. A capacidade de atribuir juízo de valor aos conceitos elaborados pela atividade científica está intimamente relacionada com aptidão ética e com a habilidade de aprender a partir de experiências vividas e refletidas.

Para exercer a profissão médica optando por uma especialidade, temos que assumi-la como um todo, tendo um olhar abrangente, mas aguçando-o com a necessidade.

Acho que chegamos ao ponto de decidir.

Fiquemos sem as seções de supra-especialidades e procuremos um meio mais seguro de aprofundarmos os nossos conhecimentos na nossa enorme especialidade.

Um grande abraço a todos os colegas OTORRINOLARINGOLOGISTAS 